\title{
ANGKA KEJADIAN ASFIKSIA NEONATORUM PADA \\ BAYI DENGAN BERAT BADAN LAHIR RENDAH DI RSUD GOETENG TAROENADIBRATA PURBALINGGA
}

\author{
Sony Andik Pratama ${ }^{1}$, Latifah Hanum ${ }^{1}$, Yuhantoro Budi HS ${ }^{1}$ \\ ${ }^{I}$ Fakultas Kedokteran, Universitas Muhammadiyah Purwokerto
}

\begin{abstract}
ABSTRAK
Latar Belakang: Angka kematian bayi di Indonesia sebagian besar disebabkan oleh berat bayi lahir rendah / BBLR (29\%) dan asfiksia (27\%). Asfiksia neonatorum adalah kegagalan bernapas secara spontan dan teratur segera setelah lahir dengan nilai APGAR $<7$. Asfksia neonatorum dapat terjadi akibat BBLR. BBLR adalah bayi yang lahir dengan berat badan lahir kurang dari 2.500 gram tanpa menilai usia kehamilan. BBLR berisiko untuk mengalami kegagalan nafas yang akan menjadi asfiksia neonatorum, hal ini dikarenakan oleh kurangnnya surfaktan berdasarkan rasio lesitin atau sfingomielin kurang dari 2, disamping itu pada BBLR pertumbuhan dan pengembangan paru belum sempurna, otot pernapasan yang masih lemah dan tulang iga yang mudah melengkung (pliable thorax) sehingga bayi akan berisiko mengalami asfiksia.

Tujuan: Mengetahui angka kejadian asfiksia neonatorum pada bayi dengan berat badan lahir rendah.

Metode: Penelitian analitik observasional dengan pendekatan crossectional, melibatkan 67 subjek penelitian berupa data rekam medis yang diambil dari RSUD Goeteng Taroenadibrata Purbalingga, analisis data menggunakan uji Chi Square.

Hasil: Hasil analisis angka kejadian asfiksia neonatorum pada bayi dengan berat badan lahir rendah didapatkan nilai $\mathrm{P}$ value $=0,716(\mathrm{P}>0,005)$

Kesimpulan: Tidak terdapat hubungan antara BBLR dengan asfiksia neonatorum

Kata Kunci: Asfiksia, BBLR
\end{abstract}

\section{ABSTRACT}

Background: Infant mortality rate in Indonesia is mostly caused by low birth weight (29\%) and asphyxia (27\%). Asphyxia Neonatorum is a respiratory failure in which a newborn fails to breathe spontaneously and regularly right after birth with APGAR score < 7. It may occur due to low birth weight (LBW). LBW is a baby born with less than 2,500 grams birth weight, without assessing the age of the pregnancy. LBW is at risk for having the respiratory failure which leads to asphyxia neonatorum. This is caused by the lack of surfactant, in which based on lecithin or sphingomyelin ratio it is less than 2. In addition to LBW, the growth and the development of the lungs have not been completed yet, the breathing muscles are still weak, and the ribs are easily curved (pliable thorax). Thus, the baby will be at risk of having asphyxia.

Objectives: finding out the number of asphyxia neonatorum occurrence on low birth weight babies.

Methods: this is an observational analytical research with a cross-sectional approach involving 67 research subjects, in the form of medical record data, taken from RSUD Goeteng Taroenadibrata Purbalingga. The data were analysed through Chi-Square test.

Result: the analysis result of asphyxia neonatorum occurrence on low birth weight babies shows that the score of $\mathrm{P}$-value $=0.716(\mathrm{P}>0,005)$.

Conclusion: there is no correlation between low birth weight with asphyxia neonatorum.

Keyword: Asphyxia, LBW 


\section{PENDAHULUAN}

Salah satu indikator dalam menilai derajat kesehatan masyarakat adalah Angka Kematian Neonatus (AKN), Angka Kematian Bayi (AKB) dan Angka Kematian Balita (AKABA). ${ }^{1}$ Menurut data hasil Survei Demografi dan Kesehatan Indonesia (SDKI) tahun 2012 AKN sebesar 19/1000 kelahiran hidup, AKB sebesar 32/1000 kelahiran hidup, AKABA sebesar 40/1000 kelahiran hidup. AKN di Jawa Tengah tahun 2015 sebesar 7,2/1.000 kelahiran hidup, AKB sebesar 10/1.000 kelahiran hidup, AKABA sebesar 11,6/1.000 kelahiran hidup ${ }^{2}$, sedangkan AKN di Kabupaten Purbalingga tahun 2015 sebesar 98/1.000 kelahiran hidup, AKB sebesar 150/1.000 kelahiran hidup dan AKABA 174/1.000 kelahiran hidup. Angka ini masih jauh dari target Milenium Development Goals (MDGs) tahun 2015 yaitu AKB diharapkan turun menjadi 23/1000 kelahiran hidup dan AKABA 32/1000 kelahiran hidup.

Menurut WHO diperkirakan sekitar 900.000 kematian bayi baru lahir setiap tahun diakibatkan asfiksia neonatorum. Kemenkes RI (2013) menyebutkan bahwa sejak tahun 2000 - 2003 asfiksia menempati urutan ke-6 yaitu sebanyak $8 \%$ sebagai penyebab kematian neonatus di seluruh dunia. ${ }^{4}$ Asfiksia neonatorum adalah kegagalan bernapas secara spontan dan teratur segera atau beberapa saat Penyebab utama kematian neonatus di Indonesia adalah berat badan lahir rendah BBLR (29\%) dan asfiksia (27\%). BBLR pada tahun 2013 di Indonesia sebanyak 10,2\%, angka kejadian BBLR tertinggi terdapat di provinsi Sulawesi Tengah $(16,8 \%)$ dan terendah di Sumatera Utara $(7,2 \%)^{4}$, sedangkan di Kabupaten Purbalingga pada tahun 2015 bayi dengan berat badan lahir rendah dilaporkan sebanyak 781 $(5.33 \%)$.

Bayi berat lahir rendah (BBLR) adalah bayi yang lahir dengan berat badan lahir kurang dari 2.500 gram tanpa memandang masa kehamilan. Penyebab terjadinya bayi BBLR secara umum bersifat multifaktorial baik itu dari faktor ibu, faktor plasenta, dan faktor janin, maupun faktor yang lain. BBLR merupakan salah satu faktor utama yang berpengaruh terhadap kematian neonatus. $^{7}$

Penelitian Afiana Rohmani menyebutkan bahwa BBLR preterm berisiko untuk mengalami kegagalan nafas yang akan menjadi asfiksia neonatorum, hal ini dikarenakan oleh kurangnnya surfaktan berdasarkan rasio lesitin atau sfingomielin kurang dari 2, disamping itu pertumbuhan dan pengembangan paru yang belum sempurna, otot pernapasan yang masih lemah dan tulang iga yang mudah melengkung (pliable thorax) dengan kondisi bayi akan berisiko mengalami hipoksia. ${ }^{7}$

Penelitian di atas memberi informasi bahwa terdapat hubungan antara asfiksia neonatorum dengan BBLR. Dalam penelitian ini, peneliti menggunakan data 
sekunder berupa rekam medik untuk melihat faktorfaktor yang menyebabkan kejadian BBLR disertai asfiksia. Berdasarkan hasil survey pendahuluan yang dilakukan di RSUD Goeteng Taroenadibrata Purbalingga bayi dengan berat badan 1000 - 2499 gram mempunyai harapan untuk bertahan hidup. Oleh karena itu, peneliti berkeinginan untuk menelaah tentang "Angka kejadian asfiksia neonatorum pada bayi dengan berat badan lahir rendah di RSUD Goeteng Taroenadibrata Purbalingga".

\section{METODE}

Jenis penelitian ini adalah observasional analitik dengan rancangan penelitian crossectional. Penelitian ini dilaksanakan di RSUD Goeteng Taroenadibrata Purbalingga pada bulan Januari 2018. Penelitian ini menggunakan populasi terjangkau yaitu seluruh pasien bayi baru lahir dengan berat badan lahir rendah pada periode bulan Januari sampai Desember tahun 2016 di RSUD Goeteng Taroenadibrata Purbalingga.

Teknik sampling yang digunakan dalam penelitian ini adalah simple random sampling. Besar sampel dibulatkan maka jumlah sampel dalam penelitian ini sebanyak 67 bayi.

Rumusan masalah bagaimana angka kejadian asfiksia neonatorum pada bayi dengan berat badan lahir rendah di RSUD Goeteng Taroenadibrata Purbalingga. Tujuan umum penelitian untuk mengetahui angka kejadian asfiksia neonatorum pada bayi dengan berat badan lahir rendah.

\section{HASIL}

Dalam penelitin ini data diambil dari RSUD Goeteng Taroenadibrata Purbalingga yaitu sebanyak 67 data rekam medis. Berdasarkan tabel I.2 didapatkan kasus BBLR sebanyak 41 kasus $(61,1 \%)$, dan BBLSR 26 kasus $(38,8 \%)$.

\section{DISKUSI}

Karakteristik yang dicantumkan pada penelitian ini diantaranya yaitu jenis kelamin, usia kehamilan, riwayat paritas ibu, riwayat persalinan ibu, riwayat penyakit ibu. Berdasarkan penelitian didapatkan bahwa jenis kelamin laki - laki paling banyak mengalami asfiksia yaitu $17(25,3 \%)$ dan perempuan $8(11,9 \%)$

Riwayat usia kehamilan pada penelitian ini dibagi menjadi tiga yaitu aterm, preterm dan postterm. Preterm apabila subyek lahir pada usia kehamilan < 37 minggu, aterm apabila subyek lahir pada usia kehamilan 3742 minggu, postterm apabila subyek lahir pada usia kehamilan > 42 minggu. Hasil penelitian menunjukkan bahwa bayi dengan riwayat kelahiran preterm yaitu aterm $8(11,9 \%)$, preterm $17(25,3 \%)$, sedangkan untuk usia kehamilan postterm $0(0 \%)$. Paritas ibu dibagi menjadi tiga yaitu primipara $17(25,3 \%)$, multipara 8 $(11,9 \%)$, grandemultipara $0(0 \%)$. Riwayat persalinan ibu dibagi menjadi dua yaitu pervaginam $21(31,3 \%)$ 
dan Sectio Caesarea (SC) 4 (5,9\%). Riwayat penyakit ibu dibagi menjadi lima yaitu preeklampsia $6(8,9 \%)$, Ketuban Pecah Dini (KPD) 4 (5,9\%), perdarahan post partum $0(0 \%)$, plasenta previa $0(0 \%)$, normal 15 $(22,3 \%)$

Untuk mencari adanya hubungan BBLR terhadap asfiksia neonatorum telah dilakukan analisis menggunakan uji chi squre, didapat nilai $\mathrm{P}=0,716$ yang berarti $\mathrm{H} 0$ diterima dan $\mathrm{H} 1$ ditolak. Hasil penelitian ini menunjukkan bahwa tidak terdapat hubungan yang bermakna antara bayi berat badan lahir rendah dengan kejadian asfiksia neonatorum di RSUD Goeteng Taroenadibrata Purbalingga.

Hasil penelitian ini sesuai dengan penelitian Novia yang menjelaskan bahwa berat badan lahir pada sampel penelitian bukan satu-satunya faktor risiko yang mempengaruhi terjadinya asfiksia, dikarenakan asfiksia adalah kejadian dengan multifaktorial. ${ }^{8}$ Hasil penelitian ini juga diperkuat dengan penelitian Vina yang memperoleh hasil analisis statistik yaitu nilai $\mathrm{P}=$ 0.292. Nilai tersebut menjelaskan bahwa nilai p-value > 0,05 yang berarti bahwa tidak ada hubungan antara bayi dengan berat lahir rendah dengan kejadian asfiksia neonatorum. 9

Adriana melaporkan hasil yang berbeda, bahwa berat badan lahir rendah akan menimbulkan komplikasi medis yang lebih berpengaruh terhadap morbiditas dan mortalitas janin yang dilahirkan, hal ini disebabkan oleh kekurangan surfaktan, pertumbuhan dan pengembangan paru yang belum sempurna, otot pernapasan yang masih lemah dan tulang iga yang mudah melengkung, perdarahan intraventikuler. Oleh karena itulah bayi dengan BBLR atau prematur sering menderita apneu, asfiksia berat dan sindroma gangguan pernapasan.

Bayi berat lahir rendah lebih merupakan masalah penting dalam pengelolaannya karena mempunyai kecenderungan ke arah peningkatan terjadinya infeksi, asfiksia, ikterus dan hipoglikemi. Hasil penelitian yang menunjukkan tidak adanya hubungan yang signifikan antara BBLR dengan asfiksia neonatorum dapat terjadi karena pelayanan di RSUD Goeteng Taroenadibrata yang sudah cukup baik dari segi sumber daya manusianya serta alat-alat penunjang kesehatan yang tersedia.

Tabel. I.I Uji Pearson chisquare

$\begin{array}{cc} & \text { Asymptotic } \\ \text { Value } & \text { Significance } \\ \text { Df } \quad(2-\text { sided })\end{array}$

Pearson

Chisquare

132

$1 \quad 0,716$


Tabel. I.2 Karakteristik BBLR

Asfiksia

\begin{tabular}{|c|c|c|c|c|c|c|}
\hline \multirow{2}{*}{\multicolumn{3}{|c|}{ Karakteristik }} & & \multicolumn{2}{|c|}{ Tuan Rstinsta } \\
\hline & & & $\mathrm{N}$ & $\%$ & $\mathrm{~N}$ & $\%$ \\
\hline \multirow[t]{2}{*}{ Jenis Kelamin } & Laki-Laki & & 17 & 25,3 & 20 & 29,8 \\
\hline & Perempuan & & 8 & 11,9 & 22 & 32,8 \\
\hline \multicolumn{7}{|l|}{ Riwayat Penyakit } \\
\hline & KDn & 1 & 50 & 7 & $1 \cap 1$ & \\
\hline & Preeklampsia & & 6 & 8,9 & 14 & 20,8 \\
\hline & Perdarahan Post & & 0 & 0 & 1 & 1,4 \\
\hline & n. & & & & & \\
\hline & Plasenta Previa & & 0 & 0 & 1 & 1,4 \\
\hline & Normal & & 15 & 22,3 & 19 & 28,3 \\
\hline \multirow[t]{3}{*}{ Usia Kehamilan } & Aterm & & 8 & 11,9 & 18 & 26,8 \\
\hline & Preterm & & 17 & 25,3 & 21 & 31,3 \\
\hline & Postterm & & 0 & 0 & 3 & 4,4 \\
\hline \multirow[t]{3}{*}{ Paritas } & Primipara & & 17 & 25,3 & 32 & 47,7 \\
\hline & Multipara & & 8 & 11,9 & 7 & 10,4 \\
\hline & Grandemultipara & & 0 & 0 & 3 & 4,4 \\
\hline \multirow[t]{2}{*}{ Riwayat Persalinan } & Pervaginam & & 21 & 31,3 & 28 & 41,7 \\
\hline & $\mathrm{SC}$ & & 4 & 5,9 & 14 & 20,8 \\
\hline
\end{tabular}

\section{SIMPULAN}

Berdasarkan hasil penelitian angka kejadian asfiksia neonatorum pada bayi dengan berat badan lahir rendah di RSUD Goeteng Taroenadibrata Purbalingga didapatkan kesimpulan sebagai berikut :

1. Angka kejadian asfiksia neonatorum pada bayi dengan berat badan lahir rendah yaitu 25 bayi

2. Tidak terdapat hubungan antara BBLR dengan asfiksia neonatorum.

\section{UCAPAN TERIMAKASIH}

Saya ucapkan terimakasih kepada seluruh keluarga besar dan civitas akademika Fakultas Kedokteran Universitas Muhammadiyah Purwokerto yang telah mendukung pembuatan artikel ini.

\section{REFERENSI}

1. Departeman Kesehatan RI. 2012. Manajemen Asfiksia Bayi Baru Lahir untuk Dokter. Jakarta: Departemen Kesehatan RI.

2. Dinas Kesehatan Jawa Tengah. 2015. Profil Kesehatan Provinsi Jawa Tengah. Semarang: Dinas Kesehatan Jawa Tengah.

3. Dinas Kesehatan Purbalingga.2015. Profil Kesehatan Purbalingga. Purbalingga: Dinas Kesehatan Purbalingga.

4. Kementerian Kesehatan RI. 2014. Profil Kesehatan Indonesia

5. Tahun 2013, Jakarta: Kementerian Kesehatan RI.

6. Ronald S, Bloom M, Cropley C. 2011. Texbook of Neonatal Resuscitation. $\left(6^{\text {th }}\right.$ ed). American Academy of Pediatrics.

7. Zulkarnain Zainudin, Rocky Wilar, Max F.J. 2012. Hubungan jenis persalinan dengan kejadian asfiksia neonatorum di RSUP Prof.DR.R.D.Kandou Manado. Manado : Ilmu Kesehatan Anak Universitas Sam Ratulangi. 
8. Afiani Rohmani, Lilia Dewiyanti, Prima Maulana CN. 2015. Prevalensi derajat asfiksia neonatorum pada berat badan bayi lahir rendah. Semarang : Fakultas Kedokteran Universitas Muhammadiyah Semarang.

9. Novia Fajarwati, Pudji Andayani, Lena Rosida. (2016). Hubungan Antara Berat Badan Lahir Dan Kejadian Asfiksia Neonatorum. Banjarmasin : Universitas Lambung Mangkurat.
10. Vina Oktavionita. 2017. Perbedaan Angka Kejadian Risiko Asfiksia Neonatorum Antara Bayi Kurang Bulan Dengan Bayi Cukup BulanPada Berat Bayi Lahir Rendah.

11. Adriana Palimbo, RR. Dwi Sogi SriRedjeki, Arum Kartikasari. 2015. Gambaran Faktor Penyebab Terjadinya Asfiksia Neonaturum Pada Bayi Baru Lahir Di Ruang Perinatalogi Rsu Dr. H. Moch. Ansari Saleh Banjarmasin. Banjarmasin: Dinamika Kesehatan. 